\title{
レーダによる他船ベクトル解析について
}

邤

民*.今 津 隼 馬**.杉 崎 昭 生**

\section{Target Vector Analysis Using Radar Data}

\author{
QIU Min, Hayama IMAZU and Akio M. SUGISAKI
}

\begin{abstract}
Although the radar display presents the successive of target echo, but the measurement point of the target echo is not the point of target's center, because the shape of target echo is changed by target's size, range and aspect.

This paper described about theoretical errors of the measurement point by two measurement methods, the root mean square of bearing random error obtained by experiment, and the effect of theoretical errors and measurement errors on vector analysis. Then some useful results were obtained for measurement method of target echo and vector analysis.

\section{1. は じめに}

今までの他船レーダ情報は, 自船からの相対位置, すなわち自船からの方位と距離によるポイント情報のみで ある。ここでは他船のレーダ映像が，他船の船型, 相対距離ならびにアスペクトに応でて，ある大きさを持つこ とを考慮し，他船の船体中央点と映像測定点の位置の差を理論的に求めた（理論誤差）。また観測值の偶然誤差 については実船実験により計測した。そしてこのような観測值を使用して他船ベクトル解析を行う場合の問題 点について考察してみた。この結果理論誤差を少なくする観測方法, 他船べクトル解析の閜題点ならびそ, 観測 值の理論誤差修正による他船ベクトル解析精度の向上について明らかとなったのでここに報告する。
\end{abstract}

\section{2. レーダ観測原理と理論誤差}

\section{1 レーダ観測原理}

レーダによる他船の映像は他船の船型，相対距離ならびにア スペクトに応じてある大きざを持つ。図 1 はレーダ映像前面と 他船の関係を示したものである。ここで他船の船型は船長の前 半分を棈円形，後半分を矩形としている。図から明らかなよら に，レーダ映像の前面は他船の自船（点 0 ）から見た最短距離 の部分で他船と接し (点B), その他の部分ではレーダ・ビー ム幅の影響で他船の面より自船に近い所に表われる。このため レーダ映像前面を使った測定值と, 他船の船体中央值との間に は差を生ずる。

ここでレーダ映像前面を使った二つの湘定点について考劣て みる。

i ）湘定点 $\mathrm{A}$ ：距離は図 1 の $\overline{0 \mathrm{~B}}$ ，すなわち自船から見た

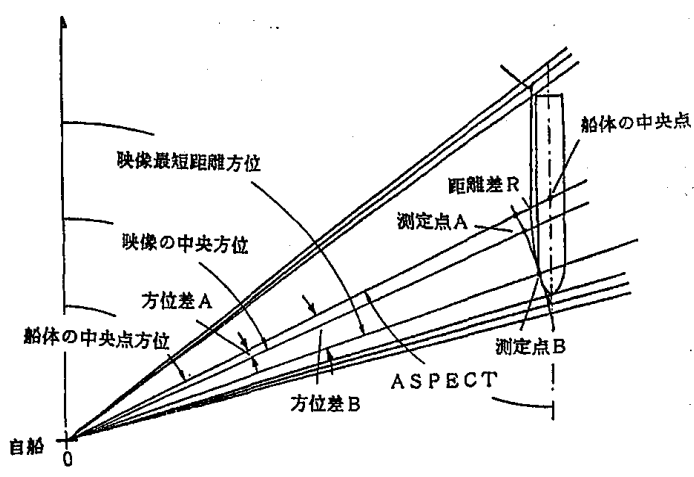

図 1 船体中央点とレーダによる観測点

* 正会員 上海船舶運輸科学研究所 (上海市民生路60号)

** 正会員 東京商船大学 (汇東区越中島 2-1-6) 
映像の最短距離とし，方位はレーダ映像前面の 2 等分線による方位（映像中央方位）により決まる点。

ii）測定点 $\mathrm{B}$ ：距離は測定点 $\mathrm{A}$ 之同様自船から見た映像の最短距離，方位は前記の最短距離測定点の方位（映

像最短距離方位）により決まる点。

この測定点と船体中央点の差は，それぞれ距離差 Rおよび方位差で表わされる。すなわち

距離差 $\mathrm{R}=$ 船体中央点距離 $-\overline{0 \mathrm{~B}}$

方位差 $A=$ 船体中央点方位一映像中央方位

方位差 $\mathrm{B}=$ 船体中央点方位一映像最短距離方位
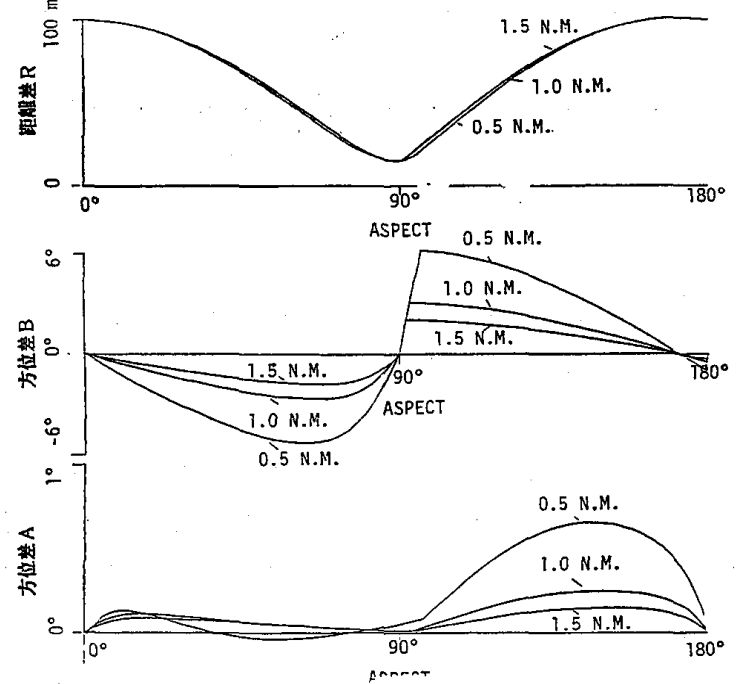

図 2 距離差と方位差のアスペクトによる変化

となる。これより船体中央点と測定点 $\mathrm{A}$ 差は距離差 $\mathrm{R}$ と方 位差 $\mathrm{A}$ により，船体中央点と測定点 $\mathrm{B}$ の差は距離差 $\mathrm{R}$ と方位 差Bにより示される。図 2 は図 1 の他船の船長を $200 \mathrm{~m}$, 船 幅を $30 \mathrm{~m}$ と，自船からの相対距離をそれぞれ0.5，1.0，1.5 海里として他船のアスペクトを $0^{\circ} \sim 180^{\circ}$ 変化させた時の距 離差 $\mathrm{R}$, 方位差 $\mathrm{A}, \mathrm{B}$ を求めたものである。ここで図の横軸 は他船アスペクトであり，縦軸は_上から距離差 $\mathrm{R}$ (単位：メ 一トル), 方位差 $\mathrm{B}$ (単位：度), 方位差 $\mathrm{A}$ (単位：度)であ る。これにより次の事が判明した。

i ）距離差Rは他船の距離にほぼ無関係で, アスペクトに 密接に関係している。距離差 Rはアスペクトが士90 敃いて最小となり，最小値は船幅の半分である。またア スペクトが $0^{\circ}$ るいは $180^{\circ}$ に近づく䚾ど最大值（船長 の半分) に近づく。

ii）方位差Bは他船の距離及びアスペクトに密接な関係が

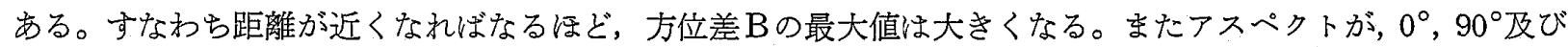
$180^{\circ}$ の時方位差Bは零となり，アスペクト $90^{\circ}$ をさんだ方位差Bの変化は非対称である。これは他船の船型

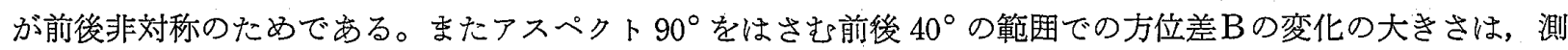
定点Bの大きな間題である。

iii）方位差A も方位差 B と同様他船の距離及びアスペクトに密接な関係がある。すなおら距離が近くなればなる

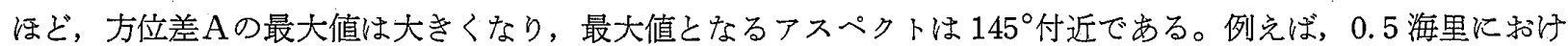
る方位差 $\mathrm{A}$ 最大值は $0^{\circ} .66$ ある。

この結果測定点 $\mathrm{A}$ と測定点 $\mathrm{B}$ 大きな違い方位差 $\mathrm{A}$ と方位差 $\mathrm{B}$ 差であることが判った。図 2 から明らがな ように方位差Bのアスペクト变化による変化は方位差 $\mathrm{A} に$ 比べ非常に大きく，またその最大值も大きいことから， 測定点 $\mathrm{B}$ は測定点として不適であると言光る。このため今後は測定点として測定点Aを採用することとする。な お測定点Aは従来のレーダによる他船測定点と一致するものである。

\section{2 レーダ情報の理論誤差}

前記の距離差 $\mathrm{R}$ おび方位差 $\mathrm{A} 以$ 外に，測定值には量子化による影響がある。通常の舶用レーダはアンテナ回 転数が約 20r.p.m.であり，パルス繰返しレートは 1,000p.p.s.である。このため方位測定值は $0^{\circ} .12$ 単位とな り，距離レンジの最小測定目盛の単位が 0.01 海里であることから，距離測定は 0.01 海里単位となる。

この量子化による誤差と前述の方位差 $\mathrm{A}$ ，距離差 $\mathrm{R} の$ 合成值を今後理論誤差と呼ぶことにする。ここでは他船 が自船の横を通過する時の測定点の理論誤差ならびにこのような測定点情報を使って求めた相対べクトル(1)の誤 差について考察した。ここで考えたケースは次の 3 ケースである。ここで自船船首方向を $\mathrm{y}$ 軸, 右正横方向を $\mathrm{x}$ 軸とする。

i）ケース 1 ：他船の自船との針路差 $180^{\circ}$ ，相対速力 12 ノット，初期相対位置 $\mathrm{x}=0.5$ 海里， $\mathrm{y}=2$ 海里。すな わち最接近距離 0.5 海里, 最接近時間10分の昜合。

ii）ケース 2 ：他船の自船との針路差 $180^{\circ}$ ，相対速力 12 ノット，初期相対位置 $\mathrm{x}=1.5$ 海里， $\mathrm{y}=2$ 海里。すな わら最接近距離 1.5 海里, 最接近時間10分の場合。

iii）ケース 3 ：他船の自船との針路差 $180^{\circ}$ ，相対速力 36 ノット，初期相対位置 $\mathrm{x}=0.5$ 海里， $\mathrm{y}=5$ 海里。すな 
わち最接近距離 0.5 海里, 最接近時間約 8.3 分の場合。

これら 3 ケースについて距離差および方位差の理論誤差と，それらのデータの 1 分間隔の值を使って求めた相 対速力，針路の誤差を図示したのが図 3 である。図の横軸は初期位置からの経過時間（単位：分）であり，矢印 は最接近時間を示す。縱軸は上から距離理論誤差 (単位：メートル), 方位理論誤差 (単位：度), 相対速力誤差 (単位：ノット)，相対針路誤差 (単位：度) である。また左から右へそれぞれケース $1,2,3$ の昜合を示す。 これにより次の事が判明した。

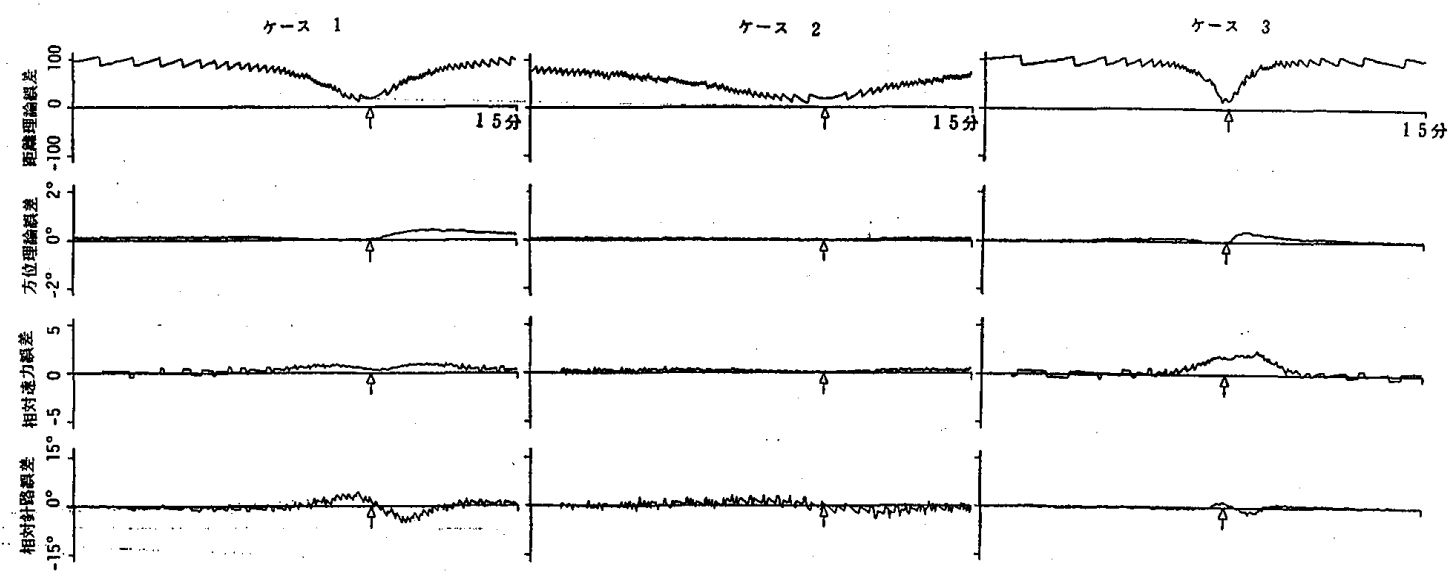

図 3 距離・方位理論誤差とベクトル解析結果

i ）距離理論誤差は最接近時間付近で最小となり，最接近距離が小さくなるほどまた相対速力が大きいほど単位 時間の変化は大きい。尼れはベクトル解析時の距離理論誤差の影響が大きい事を意味する。

ii）方位理論誤差は最接近時間直後に大きくなり，最接近距離が小さくなるほど大さくなる。また相対速力が大 きいほど単位時間の変化は大きい。しかし最接近時以前においては方位差そのものが小さいので，相対的には 若干あるものの，絶対值としてはほとんど無視できるほどである。

iii）相対速力誤差は前記のi）ii）の結果から，最接近時以前では距離理論誤差の影響を，また最接近時以後では

距離・方位理論誤差の影響を大きく受けることが判る。図から相対速力誤差は最接近時間の前後で大きくなり， 最接近距離が小さくなるほど，そして相対速力が大きくなるほど大きくなることが判る。すなわら最接近時以 前においては相対速力を実際より大き目に測定することになる。

iv）相対針路誤差は相対速力誤差と同様，最接近時以前では距離理論誤差の影響を，最接近時以後では距離・方 位理論誤差の影響を大きく受けることが判る。図から相対針路誤差は最接近距離が小さくなるほど，相対速力 が小さいほど大きくなることが判る。そして，それは最接近時以前では自船に近づくように見え，最接近時以 後は自船から遠ざかるように見える。

この結果距離・方位理論誤差がベクトル解析に及ぼす影響は，他船が近くを航過する場合大きくなる。すなわ ら自船の中心から少し外れた所に接近するような他船（衝突の恐れの大きい他船）が最接近時間に近ついた時， ベクトル解析に大きな影響を及ぼすことが判明した。

\section{3. 方位測定誤差の害験観測による推定}

さて図 1 の測定点Aを使う測定方法に括いて，方位理論誤差は今まで言われている方位測定誤差に比べ小さい ことが判った。そこで方位測定誤差（主として偶然誤差）を実験観測により求めてみた。実験は東京商船大学の 練習船汐路丸を使い昭和56年 7 月 22，23，29日に主として浦賀水道航行船について行った。図4 4 は実験により求 めたレーダ情報をもとに作成した航跡図である。図の中央プラス記号は汐路丸の位置であり，汐路丸はこの地点 で錨泊している。観測では，同一他船について1分毎にレーダによる方位と距離，それに六分儀による方位変化 量（単位時間方位変化量）を測定した。測定数は全部で 226 であった。データの解析は，六分儀による方位変化 測定值を真值とし，同一時間のレーダによる方位変化測定值との差を方位测定誤差とした。図 5 は単位時間方位 変化量を横軸にして，方位測定䛊差（単位：度）をプロットしたものである。これにより若干の例を除けばレー ダ観測者が映像の方位変化に十分追徒した事が判る。すなわわ，レーダ観測データには観測者の追従遅れはほと 


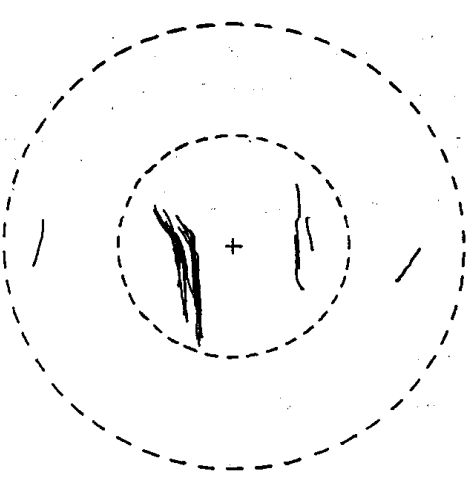

図 4 観測船航跡図 （自船中心 $5 \mathrm{~N} . M$. 範团）

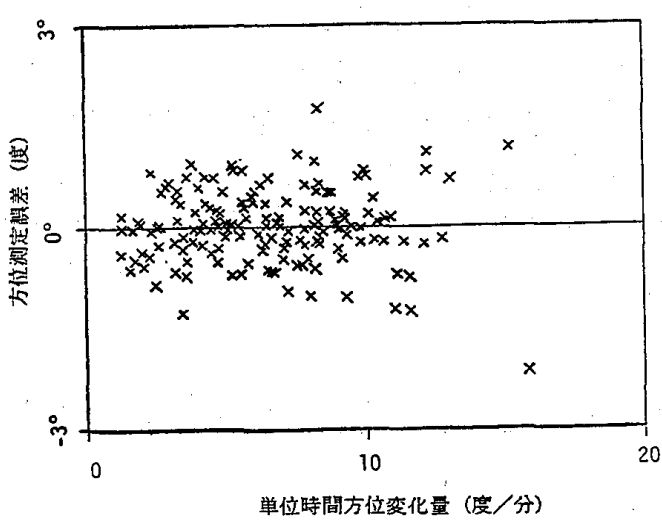

図 5 単位時間方位変化量による方位測 定詔差の分布

んどなかった。次に方位 測定誤差の距離特性につ いて求めたのが図 6 であ る。戝は横軸に自船から 他船までの距離 (単位： 海里)とし，それぞれの 距離比和汸る方位測定誤 差 (単位：度)をプロッ トしたものである。これ により方位測定誤差は距 離が近いほどバラッキが 大きくなり，遠いほどバ ラッキが小さい様子が判る。そこで方位測定誤差の各距離に招汓 る標準偏差 $\left(\sigma_{B}\right)$ を求めると

$\ln \sigma_{B}=-0.3848-0.1479 R$

で近似される。ここでRは他船までの距離である。これは図 6 の 曲線で示されるものである。また他船のアスペクトによる方位測 定誤差の特性については，測定数が不十分であることと，測定し た他船のサイズが一定ではなく，また正確なサイズが不明であっ たことから今回は求めなかった。しかしながら，図6から判明し たように，実験で求めた方位測定誤差の標準偏差は，最接近時間 以前の方位理論誤差に比べ大きいことが判明した。

\section{4. 観測誤差のベクトル解析に及ぼす影響}

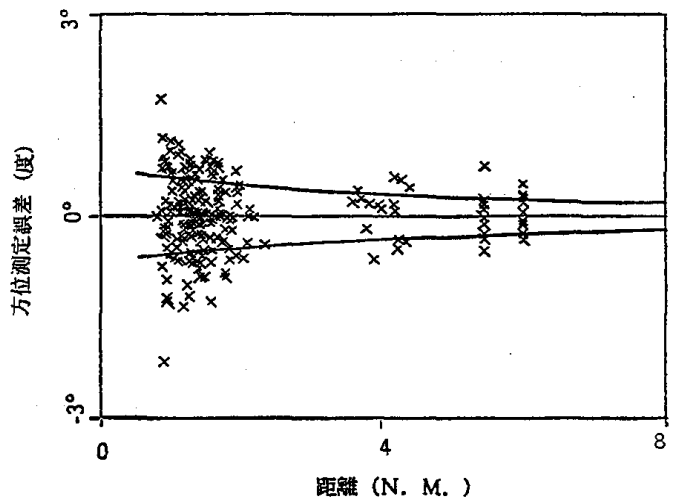

図 6 距離による方位測定誤差の分布

以上理論誤差と方位測定偶然誤差について考察したが，ここでは理論誤差と偶然誤差の合成値としての観測誤 差について考光，この観測誤差がベクトル解析にどのように影響するか調查した。まず距離観測誤差としては， 前記の距離理論誤差に IMCO の ARPA 基準(2)で用いられた距離偶然誤差（標準偏差20メートル）の合成值と し，方位観測誤差は，前記の方位理論誤差に 3.で求めた方位測定誤差（標準偏差は式(1)による）の合成値とする。 そして，他船は図 2 の時と同様とし図 3 と同様のケースについてシミニレーションを行った。図 7 はその結果を 示するのであり, 上から距離観測誤差, 方位観測誤差, そして, それらの観測值のうち1分間隔の值を使って求 めた相対速力誤差および相対針路誤差である。図の横軸怯初期位置からの経過時間（単位：分）であり，矢印は 最接近時間を示している。図の構成は図 3 亿対応するもので，左からそれぞれケース $1 ， 2$ 及び 3 の場合を示 す。これにより理論誤差のみの場合に比べ観測誤差の変動はきわめてはげしいことが言光る。なおこの図から次
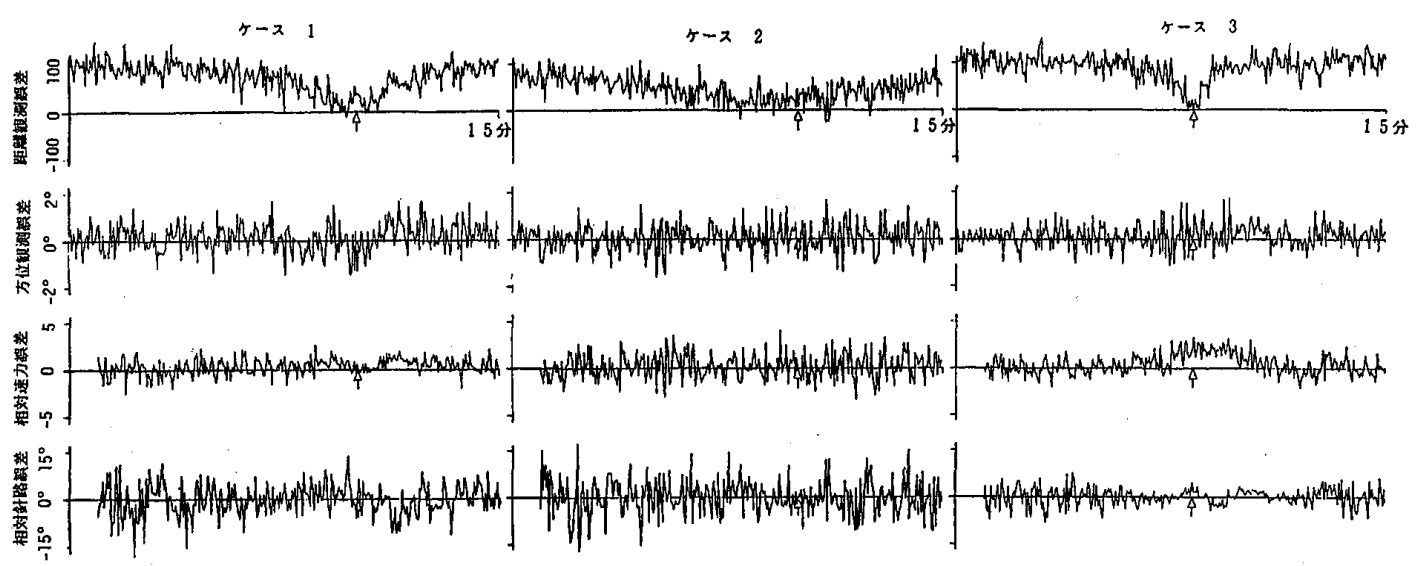

図 7 距離・方位観測誤差とベクトル解析誴差 
の事が判明した。

i）距離観測誤差の変動は距離理論誤差に比べ大きく，最大60メートル程の変動である。また全体の変動の傾向 （变化）は図 3 の場合と同様の事が言える。すなわち最接近距離が小さくなるほどまた相対速力が大きい注ど 単位時間の变化は大きい。

ii ）方位観測誤差の変動は最大 $\pm 2^{\circ}$ 程度であり，これは方位理論誤差に比べ大きなるのである。このため図 3 の時に認められた方位理論誤差の特質は図から直接読みとることはできない。

iii）相対速力誤差は最大士4ノット程度となり，理論誤差のみの場合に比べて大きい。しかし，図 3 で見られた 最接近時間付近の特質はここでも同様に見受けられる。すなわら航過距離が小さいほど，相対速力が大きくな るほど，最接近時間付近の相対速力誤差は大きく，大部分は正の值となる。

iv）相対針路誤差は最大 $\pm 15^{\circ}$ 程度となり，相対速力が小さいほど大きな変動を示している。また相対速力が 大きい場合，図 3 で見られた最短時間付近の特質がここでも見られる。すなわち理論誤差の影響が見られる。 この結果偶然誤差は方位情報に大きく，またそのペクトル解析に及ぼす影響は相対速力についてはアスペクト が $0^{\circ}$ あるいは $180^{\circ}$ に近い汪ど大きく，相対針路については相対速力が小さい活ど大きいことが判った。

\section{5. まと め}

以上レーダによる距離及び方位の観測誤差について検討し た結果，これらの䛊差がベクトル解析に大きな影響を及ぼす ことが判明した。このらち理論誤差の距離差Rと方位差 $\mathrm{A} に$ ついては，他船の船型，距離ならびにアスペクトが判明すれ ば修正可能なものである。そこで前記の実船実験の時得られ

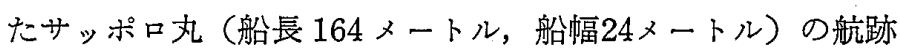
について, 測定点 $\mathrm{A}$ の航跡と, 距離差 $\mathrm{R}$, 方位差 $\mathrm{A}$ により修 正した点の航跡を比較してみた。図8はとれぞれの点の航跡 を比較したものである。これより，測定点Aを修正した点の 航跡の方が測定点Aの航跡より遠目に出て和り，またなめら かになる事が判明した。

ここで今回の研究結果をまとめると

i）方位測定は映像中央方位を測定するのが良い。

ii）距離測定は映像の最短距離のみが, 自船と他船の間の本 当の距離となるのでこの距離を測定すること。

iii）方位測定偶然誤差は式(1)で示されるような標準偏差を持 つ值である。

iv ）湘定点 Aを修正し, 船体中央点の座標とするには距離差

$\mathrm{R}$ と方位差 $\mathrm{A}$ による修正が必要である（図 2 参照）。

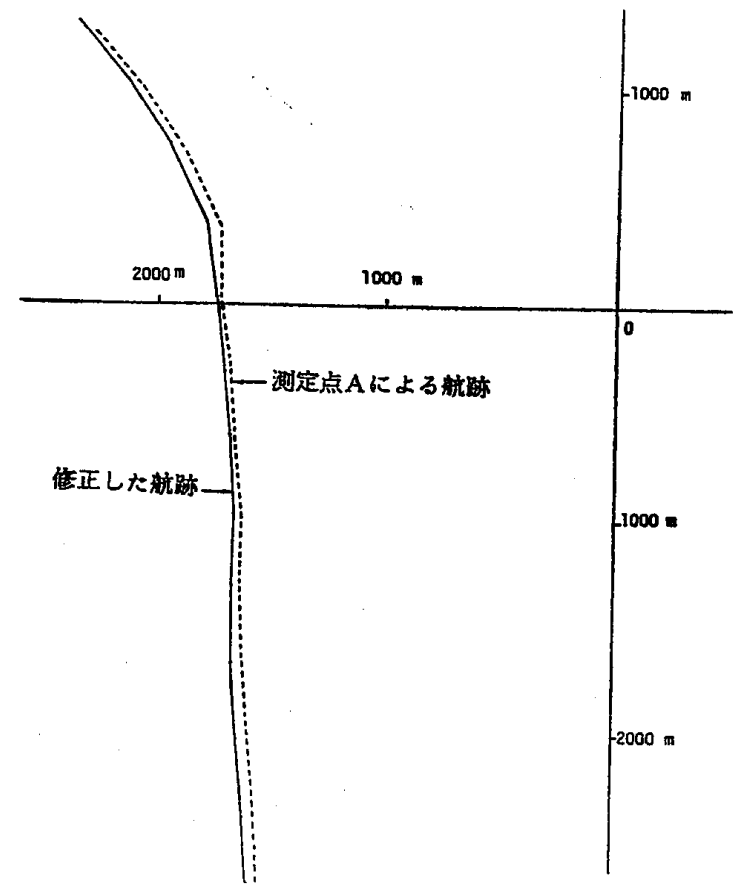

図 8 サッポロ丸航跡図

v）測定点 Aの理論誤差のベクトル解析に及ぼす影響は，他船が最接近時間に近くなるほど大きく，また最接近

距離が小さい汪ど大きくなる。

等である。この研究ではまだ実験観測によりデータを補充しなければならない部分（たとえば方位測定誤差のア スペクト特性）があり，また他船船体中心点の推定の精度をあげる具体的な方法の開発等残された問題がある。 これらの䦕題については今後検討したいと考兄ている。

\section{考 文 献}

（1）今津隼馬：衝突危険度の判定と避航処置, 避航操船シンポジゥム, 日本航海学会, 昭和52年 3 月

(2) Report of the Intersessional Working Group on Collision Avoidance System, IMCO NAV XXIII/3, June 1979 